University of New England

DUNE: DigitalUNE

2019

\title{
Latest Documented Fall Record Of Oporornis Agilis (Connecticut Warbler) In North America
}

Noah G. Perlut

University of New England, nperlut@une.edu

Follow this and additional works at: https://dune.une.edu/env_facpubs

Part of the Ornithology Commons

\section{Recommended Citation}

Perlut, Noah G., "Latest Documented Fall Record Of Oporornis Agilis (Connecticut Warbler) In North America" (2019). Environmental Studies Faculty Publications. 35.

https://dune.une.edu/env_facpubs/35

This Article is brought to you for free and open access by the Environmental Studies Faculty Works at DUNE: DigitalUNE. It has been accepted for inclusion in Environmental Studies Faculty Publications by an authorized administrator of DUNE: DigitalUNE. For more information, please contact bkenyon@une.edu. 


\title{
Latest Documented Fall record of Oporornis agilis (Connecticut Warbler) in North America
}

\author{
Noah Perlut ${ }^{*}$
}

\begin{abstract}
On 11 November 2017, a male hatch-year Oporornis agilis (Connecticut Warbler) was killed by a Felis catus (Domestic Cat) in Scarborough, Cumberland County, ME. This specimen, housed in the University of New England ornithological collection, is the latest documented fall record of this species in North America.
\end{abstract}

During fall migration, Oporornis agilis (Wilson) (Connecticut Warbler) migrate south and east from their breeding grounds to the eastern coast of North America before flying over open ocean to islands in the eastern Caribbean and then to South America (McKinnon et al. 2017). On 11 November 2017, a male hatch-year Connecticut Warbler was killed by a Felis catus (L.) (Domestic Cat) near Thomas Drive, Scarborough, Cumberland County, ME (latitude $43.5589^{\circ} \mathrm{N}$, longitude $70.3200^{\circ} \mathrm{W}$ ). To my knowledge, this is the latest verified fall record of Connecticut Warbler in mainland North America, and is notably later than other records for the northeastern US. The latest bird-banding capture of Connecticut Warbler at equal or greater latitude in North America is 15 October (Alpena, Michigan; USGS 2018). Peak frequency of reports along the east coast of the US is 15 September, with nearly all migrants occurring from late August to late October (eBird 2018a).

Previously, the latest record for Maine was a sight record with photographs from 12 October 2015 in York County (eBird 2018b). From north to south, latest reported sight records or banding records (USGS 2018) for this species include: Ontario 19 October (USGS 2018), Nova Scotia 18 October (McLaren 2012), New Hampshire 13 October (Keith and Fox 2013), Vermont 21 October (eBird 2018c), Massachusetts 26 October (Veit and Petersen 1993), Rhode Island 27 October (USGS 2018), Connecticut 31 October (Zeranski and Baptist 1990), New York 30 October (Levine 1998), New Jersey 31 October (USGS 2018), Delaware 24 October (Hess et al. 2000), Maryland 7 November (Stewart and Robbins 1958), Virginia 29 October (USGS 2018), and Bermuda 3 November (eBird 2018d).

Connecticut Warbler vacates mainland North America during winter (Pitocchelli et al. 2012). Although Christmas Bird Counts spanning 15-31 December from 1967 to 2013 have reported the species 14 times (National Audubon Society 2018), none of those observations is documented by a photograph, preserved specimen, or measurements. A banding report for 16 November at Vero Beach, FL (USGS 2018), may constitute a later fall record than the Maine bird, although this record is also not documented by a photograph or measurements. Connecticut Warbler is frequently misidentified, especially in fall when immatures and females can be confused with both Geothlypis philadelphia (Wilson) (Mourning Warbler) and G. trichas (L.) (Common Yellowthroat) and vice versa. In fact, I originally misidentified this bird as a Mourning Warbler, until more detailed study of its plumage and morphology identified it as a Connecticut Warbler. Therefore, verifiable evidence in the form of a photograph or specimen is often necessary to document extra-limital records and extreme dates of occurrence.

\footnotetext{
"University of New England, Department of Environmental Studies, 11 Hills Beach Road, Biddeford, ME04005; nperlut@une.edu.
}

Manuscript Editor: Jeremy Kirchman 


\section{N. Perlut}

I made the following morphological measurements, which allowed diagnostic identification, from the Maine specimen: wing chord $=67.5 \mathrm{~mm}$, flattened wing length $=68 \mathrm{~mm}$, length of p9-length of p6 $=5.5 \mathrm{~mm}$, tail $=49 \mathrm{~mm}$, tarsus $=20.71 \mathrm{~mm}$, bill width $=2.90$ $\mathrm{mm}$, bill length $=8.08 \mathrm{~mm}$, bill depth $=3.16 \mathrm{~mm}$, mass $=13.8 \mathrm{~g}$, spread wing $=160 \mathrm{~mm}$, and total body length $=130 \mathrm{~mm}$. I sexed the bird as male (testes present), and aged it as a hatch-year in formative plumage (juvenile rectrices pointed; incomplete skull ossification). The wing chord exceeded the known maximum for Mourning Warbler, and the p9-p6 difference was likewise longer than known for Mourning Warbler (Lanyon and Bull 1967, Pitocchelli et al. 2012). The Maine specimen shows a bold, whitish-buff eye ring combined with a brownish buff throat cut off sharply at the breast, characteristic of the Connecticut Warbler. The Mourning Warbler has, at most, a thin eye ring that is narrowly broken both anteriorly and posteriorly, a yellow wash to the chin and throat, and lacks a sharp border between throat and breast. A narrow break in the eye ring posteriorly behind the eye often occurs on immature Connecticut Warblers, as was the case for the Maine bird. Its dull yellow underparts also differed from the bright yellow typical of the Mourning Warbler. The specimen is housed in the Department of Environmental Studies ornithology collection at the University of New England, Biddeford, ME (reference identification: UNE 057). I encourage others to make careful observations and measurements of this species, where possible, to provide a more detailed understanding of the location and timing of movement by Connecticut Warblers. Finally, this record serves as a continuing call to mediate the impacts of free-ranging Domestic Cats on birds (e.g., Loss et al. 2013), including relatively rare species like the Connecticut Warbler.

Acknowledgments. This work was supported by the University of New England. Major thanks to L. Bevier, for his thoughtful support. E. White took all morphological measurements; L. Moser prepared the specimen for the museum collection. CBC Data is provided by National Audubon Society and through the generous efforts of Bird Studies Canada and countless volunteers across the western hemisphere.

\section{Literature Cited}

eBird. 2018a. Bird observations: Connecticut Warbler. eBird: An online database of bird distribution and abundance, Ithaca, NY. Available online at https://ebird.org/barchart?r=8,12,13\&bmo=1\&em $\mathrm{o}=12 \&$ byr $=1900 \&$ eyr $=2017 \& \mathrm{spp}=$ conwar. Accessed 26 April 2018.

eBird. 2018b. Checklist S25388571: Observations for Mon 12 October 2015 at Rachel Carson NWR, ME. eBird: An online database of bird distribution and abundance. Ithaca, NY. Available online at https://ebird.org/view/checklist/S25388571. Accessed 26 April 2018.

eBird. 2018c. Checklist S15460554: Observation for Mon 21 October 2013 at Snow Valley Road in Winhall, VT. eBird: An online database of bird distribution and abundance, Ithaca, NY. Available online at https://ebird.org/ebird/vt/view/checklist/S15460554. Accessed 26 April 2018.

eBird. 2018d. Checklist S240281947: Observations for Fri 3 November 2017 at Ferry Point Park, Bermuda. eBird: An online database of bird distribution and abundance, Ithaca, NY. Available online at https://ebird.org/ebird/view/checklist/S40281047. Accessed 26 April 2018.

Hess, G.K., R.L. West, M.V. Barnhill III, and L.M. Fleming. 2000. Birds of Delaware. University of Pittsburgh Press, Pittsburgh, PA. 656 pp.

Keith, R., and R.P. Fox. 2013. The Birds of New Hampshire. Memoirs of the Nuttall Ornithological Club No. 19. Cambridge, MA. 469 pp.

Lanyon, W.E., and J. Bull. 1967. Identification of Connecticut, Mourning, and MacGillivray's Warblers. Bird-Banding 38:187-194.

Levine, E. 1998. Bull's Birds of New York State. Comstock Publishing Associates, Ithaca, NY. 592 pp.

Loss, S.R., T. Will, and P.P. Marra. 2013. The impact of free-ranging Domestic Cats on wildlife of the United States. Nature Communications 4:1396. 
N. Perlut

McKinnon, E.A., C. Artuso, and O.P. Love. 2017. The mystery of the missing warbler. Ecology 98:1970-1972.

McLaren, I. 2012. All the Birds of Nova Scotia. Gaspereau Press, Kentville, NS, Canada. 336 pp.

National Audubon Society. 2018. The Christmas Bird Count historical results. Available online at http://www.christmasbirdcount.org. Accessed 1 May 2018.

Pitocchelli, J., J. Jones, D. Jones, and J. Bouchie. 2012. Connecticut Warbler (Oporornis agilis), version 2.0. In A.F. Poole (Ed.). The Birds of North America. Cornell Lab of Ornithology, Ithaca, NY. Accessed 1 November 2018.

Stewart, R.E., and C.S. Robbins. 1958. Birds of Maryland and the District of Columbia. North American Fauna: Number 62. 401 pp.

US Geological Survey Bird Banding Laboratory (USGS). 2018. North American bird banding and band-encounter data set. Patuxent Wildlife Research Center, Laurel, MD. Available online at https://www.pwrc.usgs.gov/BBL/homepage/start.cfm. Accessed 26 April 2018.

Veit, R.R., and W.R. Petersen. 1993. Birds of Massachusetts. Massachusetts Audubon Society, Lincoln, MA. 514 pp.

Zeranski, J.D., and T.R. Baptist. 1990. Connecticut Birds. University Press of New England, Lebanon, NH. 328 pp. 